\title{
Refundação e novos caminhos democráticos na América Latina
}

Matheus Alexandre de Araújo

PEREIRA, D. S. F. Democracias Errantes: reflexões sobre as experiências participativas na América Latina. 1. ed. Rio de Janeiro, RJ: Ponteio, 2015.

A leitura de Fabricio Pereira da Silva, em Democracias Errantes, sobre as experiências participativas na América Latina é inovadora, na medida em que lança outro olhar sobre elas e propõe um entendimento heterogêneo de democracia. Utilizando-se do método comparativo, o autor trata da Venezuela, da Bolívia e do Equador como um grupo específico, mas sem apagar suas diferenças e mostrando, de forma criativa, as novidades nesses processos, que, por vezes, são mal analisados pelas correntes hegemônicas da Ciência Política.

Destaca o fenômeno da "onda rosa", a emergência de lideranças e governos de esquerda no subcontinente, diferenciando-se da leitura majoritária, que divide essas esquerdas em dois tipos ideais: a boa, democrática e respeitosa das instituições e a má, populista e autoritária. Para ele, a melhor definição, no entanto, seria entre esquerdas "renovadoras" e "refundadoras". Embora políticas sociais façam parte de todas as experiências, as primeiras são caracterizadas por maior grau de integração ao sistema político, com propostas "neodesenvolvimentistas" e com crítica moderada ao neoliberalismo, enquanto que as segundas teriam maior incidência na definição do papel do Estado e na negação do neoliberalismo, propondo, ainda, reformas estruturais. As experiências refundadoras seriam: a "Revolução Bolivariana", na Venezuela,

\section{$\overline{\text { Matheus Alexandre de Araújo }}$}

Graduando do curso de Ciências Sociais na Universidade Federal do Ceará.

E-mail: matheus.alexander17@outlook.com 
a "Revolução Democrática e Cultural", na Bolívia e a "Revolução Cidadã", no Equador.

O autor recorre à teoria democrática, afirmando ser o conceito de democracia polissêmico e que as experiências refundadoras costumeiramente são analisadas a partir de parâmetros hegemônicos os quais ele chama de "procedimentais" ou "elitistas". Assim sendo, ele sugere que não há noção universal de democracia. E, para fundamentar esse argumento, retoma a constituição histórica do conceito, lembrando que o sistema representativo só passou a ser hegemônico com o encontro de correntes da democracia e do liberalismo, colocando outras noções de democracia em posição contra-hegemônica. Elenca três correntes que considera minoritárias: o participacionismo, o deliberacionismo e o republicanismo.

Sua análise das formulações discursivas dos processos refundadores constata que esses movimentos esforçam-se em retomar elementos nacionais e personagens/heróis históricos de forma reformada e progressista, apresentando-os como construções ideológicas de uma "democracia verdadeira", em detrimento das antigas concepções antinacionais e antipopulares que se pretende superar. De certo modo, retomam o passado para construir um novo futuro.

O bolivarianismo, por exemplo, é proposto como um legado democrático e popular de Simón Bolívar. Essa herança seria interpretada por Hugo Chávez e seus partidários sob três eixos: independência nacional, soberania popular e justiça social. Outro marcador do processo de refundação, na Venezuela, seria a formulação do socialismo do século XXI ou socialismo bolivariano do século XXI, um socialismo venezuelano e latino-americano. Já a ideia de democracia comunitária ou socialismo comunitário, que ganhou expressão na Bolívia, estrutura uma noção de participação com valores do "bem viver/viver bem" que possui como núcleo comum uma relação homem-natureza calcada na igualdade, remetendo a valores indígenas. Essa noção articula discursivamente, também, o processo refundador equatoriano que, por sua vez, deve ser pensado como uma harmonização de ingredientes: um cristianismo em chave progressista, propondo o socialismo cristão, um conteúdo ecológico e republicano, propondo o 
socialismo do bem-viver e o alfarismo, resgatando a figura de Eloy Alfaro que atuou como presidente do Equador e teve papel central na Revolução Liberal de 1895. Alfaro é retomado como expressão de um liberalismo radical, a luta por cidadania ampliada, justiça social e latino-americanismo.

Por meio de uma análise das instituições desenvolvidas nos três casos, o estudioso não hesita em afirmar que houve uma ampliação do "experimentalismo democrático", introduzindo transformações nos mecanismos de participação e representação. No caso chavista, a organização de uma democracia direta na base, focada no cidadão comum "desorganizado", promoveu um efetivo empoderamento com índices notáveis de inclusão popular, ainda que estes organismos sejam impostos "de cima para baixo" e dependam de recursos oficiais, sugerindo influência estatal. Semelhantemente, o autor propõe a Revolução Cidadã como fenômeno inorgânico, pois tem como foco a participação individual do cidadão, embora exista espaço para a participação coletiva nos Conselhos Cidadãos Setoriais e nos Conselhos Nacionais para a Igualdade. Diferentemente desses dois casos, a experiência boliviana tem como público-alvo a "sociedade civil organizada", como definido na carta constitucional, tendo os movimentos indígenas um papel de destaque.

Pereira da Silva define padrões de interação Estado-Sociedade. Os movimentos sociais reflexo-dependentes teriam baixo grau de autonomia ante os partidos ou o Estado, dificultando a produção de pauta própria. Os moderadamente autônomos possuiriam diálogo com os partidos, porém preservando iniciativa e estrutura própria. Já as organizações radicalmente autônomas evitariam tais vínculos, definindo a autonomia como elemento essencial de sua atuação. Segundo o autor, parte das organizações venezuelanas mantém uma ligação de reflexo-dependência com o Estado, havendo, ainda, movimentos com uma autonomia moderada e outros em uma posição de autonomia radical, mas com reflexo-dependência ou autonomia moderada em relação aos partidos de oposição. No Bolívia, existem grupos que assumem uma relação de maior subordinação, como é o caso da Coordenadora Nacional pela Mudança, criada desde o governo, enquanto outros 
se conservam mais afastados, indo do "apoio crítico" a momentos de quase oposição. Finalmente, no processo refundador equatoriano as associações e coletivos têm mantido uma postura de autonomia e até mesmo oposição à Revolução Cidadã, enquanto o governo se esforça em fomentar novos movimentos em diversas áreas.

A obra de Fabricio Pereira da Silva é, de fato, uma tentativa de abordar o tema da democracia e as experiências refundadoras da Venezuela, da Bolívia e do Equador, a partir de ângulos alternativos, compreendendo a democracia como conceito polissêmico e passível de desenvolvimento. Ademais, aponta potencialidades e problemas das novas formas participativas em construção nesses países. Afirma que, embora instituições de base tenham estimulado o protagonismo da cidadania, como é o caso dos Conselhos Comunais venezuelanos e as Autonomias Indígenas Originárias Camponesas bolivianas, a participação em níveis superiores seria meramente consultiva e sem poder decisório no desenho de políticas públicas. Na Bolívia, a consulta é feita de forma direta pelo Poder Executivo, através do Vice Ministério de Coordenação com os Movimentos Sociais, enquanto na Venezuela, o Estado não se apresenta permeável à interferência popular no planejamento governamental. Seguindo um fundamento meritocrático, no Equador, o Conselho de Participação Cidadã e Controle Social é estruturado sob uma direção de conselheiros selecionados por concurso público. Nesse caso, o "mérito" é enfatizado como um critério central para a sua composição, constituindo um elemento tecnocrático da Revolução Cidadã. Outro ponto é a "democratização do processo produtivo", sendo a Venezuela o único processo com propostas no campo da "autogestão" de empresas estatizadas ou reestatizadas, enquanto que nos governos de Rafael Correa e Evo Morales simplesmente não se avançou nessa direção.

Democracias Errantes acrescenta outros dados ao debate já abordado pela literatura especializada. A perspectiva é de uma teoria democrática alargada, que entende ser possível buscar novas formas de participação popular, para além das instituições liberais. Pereira da Silva realçou o que classifica como "democratização paradoxal": a destruição de elementos importantes 
da democracia representativa nessas experiências, sobretudo na Venezuela. Porém, ele não aponta quais são esses componentes nem os analisa. Teria sido interessante uma abordagem que colocasse essa contradição em paralelo, sem perder o foco do livro nos novos mecanismos de participação, mas o principal que se extrai do livro é a séria reflexão de que, para compreender tais experiências políticas em curso, é necessário colocar em discussão uma pluralidade de democracias, a "demodiversidade". 